DOI $10.14746 /$ ps.2015.1.31

\title{
Tomasz R. Aleksandrowicz, Świat w sieci. Państwa, spoleczeń- stwa, ludzie. W poszukiwaniu nowego paradygmatu bezpieczeń- stwa narodowego, Difin, Warszawa 2014, ss. 257.
}

Zmiany, jakie nastapiły w stosunkach międzynarodowych na przestrzeni ostatnich kilkudziesięciu lat, wywarły znaczący wpływ na większość sfer ludzkiego życia. Upadek świata dwubiegunowego, postęp technologiczny, procesy globalizacyjne, wzrost współzależności czy też pojawienie się nowych podmiotów w stosunkach międzynarodowych sprawiły, że zmieniła się również rola i pozycja państwa we współczesnym świecie. To z kolei wiąże się z koniecznością nowego postrzegania kwestii bezpieczeństwa, którego przedmiot, jak i podmiot uległ przemianom.

Uwzględniając dokonujące się zmiany w stosunkach międzynarodowych po zakończeniu zimnej wojny oraz ich wpływ na bezpieczeństwo państwa, Tomasz Aleksandrowicz w swoim najnowszym dziele podjął próbę zdefiniowania nowego paradygmatu bezpieczeństwa narodowego i międzynarodowego. Autor chciał w ten sposób uzupełnić dotychczasowe postrzeganie tego zagadnienia, wywodzące się ze szkoły realistycznej, neoliberalnej i konstruktywistycznej, o realia świata multicentrycznego, w którym ważną rolę odgrywają podmioty pozapaństwowe. Do osiągnięcia zamierzonego celu posłużył się koncepcją społeczeństwa sieciowego i sieciocentryczności. Koncepcja ta zakłada, że państwa z jednej strony posiadają strukturę sieciową, a z drugiej same funkcjonują w sieci jako środowisku działania, co zdaniem Autora determinuje kształt współczesnego bezpieczeństwa narodowego.

Książka składa się z 8 rozdziałów oraz wprowadzenia, zakończenia i bibliografii. Znajdują się w niej ponadto wykresy i tabele, które stanowią przejrzyste i syntetyczne uzupełnienie omawianych zagadnień. Walorem pracy są również zamieszczone na końcu każdego rozdziału podsumowania zawierające zwięźle sformułowane wnioski. Interdyscyplinarne podejście do tematu przejawia się w odwołaniu się do dorobku różnych dziedzin nauki w poszczególnych częściach publikacji.

W pierwszym rozdziale Tomasz Aleksandrowicz podjął się analizy zmian na arenie międzynarodowej, które nastapiły po rozpadzie Związku Radzieckiego. Porusza w nim również zagadnienie wzrostu współzależności, postępujących procesów globalizacyjnych i zmiany układu sił. Główną uwagę poświęca zmianie pozycji państwa w stosunkach międzynarodowych ze względu na pojawienie się nowych podmiotów niepaństwowych.

Drugi rozdział traktuje o zmianach dokonujących się w dziedzinie technologii komunikacyjnych. W tym miejscu opisane zostały również kwestie związane z pojawieniem się społeczeństwa informacyjnego i znaczenia informacji w rozwoju sieci społecznych oraz cyberprzestrzeni. Wszystko to zostało poruszone w kontekście wpływu na bezpieczeństwo państwa i funkcjonowanie społeczeństwa.

W trzeciej części, wykorzystując dorobek wcześniejszych badań, przeanalizowano zmiany, jakie nastąpiły w środowisku bezpieczeństwa pod względem przedmiotowym i podmiotowym. Autor zwrócił uwagę na nasilenie się zagrożeń o charakterze pozamilitarnym, a także pojawienie się nowych podmiotów generujących zagrożenie.

Czwarty rozdział odnosi się do funkcjonowania państwa i społeczeństwa w świetle zachodzących zmian cywilizacyjnych. Rozważania skupiają się na przedstawieniu zarówno pozytywnych, jak i negatywnych skutków tego zjawiska. 
Piąta część publikacji poświęcona została regulacjom prawnomiędzynarodowym w zakresie użycia siły. Skonfrontowano normy dotyczące uprawnienia do użycia siły zbrojnej w stosunkach międzynarodowych oraz dozwolonych środków i sposobów walki z panującymi realiami. Skłoniło to Autora do rozważań na temat aktualności obowiązujących regulacji i praktyk stosowanych przez państwa w kwestii ich interpretacji.

Rozdział szósty to próba wypracowania nowego sieciowego paradygmatu bezpieczeństwa. Posłużyła temu analiza relacji zachodzących między podmiotem, przedmiotem a środowiskiem bezpieczeństwa. Przeprowadzone badania wskazały na konieczność odejścia od państwo-centrycznego postrzegania stosunków międzynarodowych oraz występowania sieciowego charakteru wewnętrznych i zewnętrznych relacji państwa.

W siódmym rozdziale poddano analizie dokumenty strategiczne Stanów Zjednoczonych, ChRL, Rosji, Francji, Wielkiej Brytanii, Czech, Słowacji, Ukrainy, Litwy, Izraela i Szwajcarii. Ponadto znaczącą część rozdziału poświęcono na studia Strategicznego Przeglądu Bezpieczeństwa Narodowego Rzeczpospolitej Polskiej w latach 2010-2012. Badanie to miało na celu zweryfikowanie, czy w strategiach bezpieczeństwa wyżej wymienionych państw sieciowy paradygmat bezpieczeństwa znajduje swoje praktyczne odzwierciedlenie.

Ostatnia ósma część książki to prognoza na przyszłość. Tomasz Aleksandrowicz przedstawił w tym miejscu autorską wizję środowiska bezpieczeństwa w perspektywie kolejnych 25 lat. Jest to na pewno śmiałe rozwiązanie, biorąc pod uwagę tempo zmian i nasz ograniczony wpływ na nie. Uwzględniając jednak przy tym dystans, z jakim Autor podchodzi do tej próby, z pewnością jest to jeden z najciekawszych i najbardziej intrygujących fragmentów publikacji.

Książka Tomasza Aleksandrowicza jest warta polecenia nie tylko osobom zajmującym się problematyką bezpieczeństwa narodowego, ale także wszystkim tym, którzy szerzej interesują się współczesnymi stosunkami międzynarodowymi. Jednocześnie ze względu na logiczne i przejrzyste przedstawienie omawianych problemów oraz zrozumiały język publikacji stanowi ona ciekawą pozycję również dla osób spoza świata nauki. Ponadto liczne przykłady, jakie przytacza Autor, utwierdzają czytelnika w przekonaniu o aktualności poruszanych przez niego kwestii. Niemniej jednak skompresowanie tak obszernego zagadnienia, jakim jest bezpieczeństwo narodowe i co więcej, próba przedstawienia go z różnych, złożonych perspektyw w stosunkowo niewielkiej objętościowo książce, może pozostawiać pewien niedosyt. Warto zatem potraktować tę lekturę jako bazę do dalszej wnikliwej analizy omawianego tematu.

Aleksandra GOLUS

Poznań 